\title{
The evaluation of variants, subtypes and atypical forms of mycosis fungoides in a tertiary hospital
}

\author{
Üçüncü basamak bir hastanedeki mikozis fungoides, mikozis fungoides varyantları, \\ alt tipleri ve atipik formlarının klinikopatolojik değerlendirilmesi
}

\section{Hilal Kaya Erdoğan, ๑ Esra Ağaoğlu, ๑ Ersoy Acer, ๑ Deniz Arı**, ๑ Zeynep Nurhan Saraçoğlu}

Eskișehir Osmangazi Unıversity Faculty of Medicine, Department of Dermatology; *Department of Pathology, Eskișehir, Turkey

\begin{abstract}
Background and Design: Clinical variants, subtypes, and early mycosis fungoides (MF) lesions may mimic other dermatoses. MF is the most common type of cutaneous T-cell lymphomas. In our study, we aimed to evaluate the clinical and histopathological features of patients with classical and variants, subtypes, or atypical forms of MF in our dermatology department.

Materials and Methods: We retrospectively evaluated MF patients who were followed up in our dermatology department between 2008 and 2018. Demographic features (age and gender), duration of disease, clinical findings, stages, and treatments of patients with classical and atypical variants of MF were evaluated.

Results: A total of 117 patients diagnosed clinically and histopathologically with MF were included in the study. Sixty-four of the patients were female (54\%), and 53 were male (46\%). The mean age at diagnosis was $55.6 \pm 16.03$ years. The mean disease duration was 5.6 years. Sixtyone patients $(52.1 \%)$ had stage IA, 20 patients $(17 \%)$ had stage IB, 31 patients $(26.4 \%)$ had stage IIA, three patients $(2.5 \%)$ had IIB stage, one patient $(0.85 \%)$ had IIIB stage and one patient $(0.85 \%)$ had stage IVA disease. Atypical forms of the disease were detected in six patients (5.1\%). Three (2.5\%) of these cases were follicular MF, and one patient for each type of hypopigmented, ichthyosiform, and granulomatous MF. In addition to topical steroids, 99 patients (84.6\%) received phototherapy, 20 patients (17\%) had acitretin, six patients (5.1\%) had topical bexarotene, four patients (3.4\%) had methotrexate and one patient $(0.85 \%)$ had systemic interferon treatment.

Conclusion: MF variants, subtypes, atypical forms, and early lesions of MF may cause a delay in the diagnosis and treatment by mimicking other dermatoses. Suspicion of MF is warranted for early diagnosis and treatment of MF variants, subtypes, atypical forms of MF.
\end{abstract}

Keywords: Mycosis fungoides, atypical, variant

Öz

Amaç: Mikozis fungoides (MF) en sık görülen kutanöz T hücreli lenfoma tipidir. MF'nin erken lezyonları, alt tipleri ve klinik varyantları, diğer dermatozları taklit edebilir. Çalışmamızda, hastanemiz dermatoloji kliniğinde takipli MF hastalarında klasik veya atipik seyir gösteren varyantların klinik ve histopatolojik özelliklerini ortaya koymayı amaçladık.

Gereç ve Yöntem: Hastanemiz dermatoloji kliniğinde 2008-2018 yılları arasında takip edilen MF hastaları retrospektif olarak incelendi. Hastaların sosyodemografik özellikleri, hastalık süresi, klinik bulguları, evreleri, verilen tedaviler ve atipik varyantları kaydedildi.

Bulgular: Klinik ve histopatolojik olarak MF tanılı 117 hasta çalışmaya dahil edildi. Hastaların 64'ü kadın (\%54), 53'ü erkek (\%46) idi. Olguların yaş ortalaması 55,6 idi. Hastalığın başlangııından tanıya kadar geçen süre ortalama 5, 6 yıldı. Altmış bir hasta $(\% 52,1)$ evre IA, 20 hasta $(\% 17)$ evre IB, 31 hasta $(26,4)$ evre IIA, 3 hasta $(\% 2,5)$ evre IIB, 1 hasta $(\% 0,85)$ evre IIIB ve 1 hasta $(\% 0,85)$ evre IVA idi. Altı olguda (\%5,1) hastalığın atipik formları saptandı. Üç hasta $(\% 2,5)$ foliküler MF, birer hasta ise hipopigmente, iktiyoziform ve granülomatöz MF idi. Tedavide topikal steroidlerin yanında 99 hastaya $(\% 84,6)$ fototerapi, 20'sine $(\% 17)$ asitretin, 4'üne $(\% 3,4)$ metotreksat ve 1 hastaya $(\% 0,85)$ sistemik interferon başlandı.

Sonuç: MF varyantları, subtipleri, atipik formları ve MF'nin erken lezyonları, diğer dermatozları taklit ederek tanı ve tedavide gecikmeye neden olabilir. MF varyantlarının, alt tiplerinin ve atipik formlarının erken teşhisi ve tedavisi için MF'den şüphelenilmesi gereklidir. Anahtar Kelimeler: Mikozis fungoides, atipik, varyant

Address for Correspondence/Yazışma Adresi: Hilal Kaya Erdoğan MD, Eskişehir Osmangazi Unıversity Faculty of Medicine, Department of Dermatology, Eskissehir, Turkey Phone: +90 5057161770 E-mail: hilalkayaerdogan@yahoo.com Received/Geliş Tarihi: 19.11.2018 Accepted/Kabul Tarihi: 06.05.2019 ORCID: orcid.org/0000-0002-8172-1920

CCopyright 2019 by Turkish Society of Dermatology and Venereology

Turkderm-Turkish Archives of Dermatology and Venereology published by Galenos Yayınevi. 


\section{Introduction}

Mycosis fungoides (MF) is the most common type of cutaneous T-cell lymphomas, characterized with proliferation of atypical epidermotropic CD4+ lymphocytes ${ }^{1,2}$. In addition to the classical type of MF, there are many clinicopathological variants such as hypopigmented, hyperpigmented, hyperkeratotic/verrucous, vegatative/papillomatous, bullous, pustular, porokeratotic, poikilodermic, folliculotropic/ follicular, syringotrophic, granulomatous, ichthyosiform, erythrodermic, palmoplantar, unilesional and pityriasis lichenoides like. They differ clinically and histopathologically from classical type of $\mathrm{MF}^{1,3-5}$. These variants and subtypes can also be referred to as atypical forms. Clinical variants, subtypes and early MF lesions may mimic other benign dermatoses which might lead to delay in the diagnosis and treatment ${ }^{5,6}$. In our study we aimed to evaluate the demographic, clinical and histopathological features of patients with classical and variants, subtypes or atypical forms of MF in our dermatology department.

\section{Materials and Methods}

We evaluated MF patients who were followed up in our dermatology department between 2008-2018 retrospectively. Demographic features (age and gender), duration of disease, clinical findings, stages and treatments of patients with classical and atypical variants of MF were evaluated.

The study protocol was approved by Eskişehir Osmangazi University Ethics Committee (approval number: 11, date: 03.07.2018).

\section{Statistical Analysis}

SPSS 22.0 software was used for data analysis. Continuous quantitative data were expressed as $n$, mean and standard deviation and qualitative data were expressed as $n$ and median.

\section{Results}

A total 117 patients diagnosed with MF clinically and histopathologically were included in the study. Sixty-four of the patients were female (54\%) and 53 were male (46\%). The mean age at diagnosis was $55.6 \pm 16.03$ years (range: $20-89$ years). The mean disease duration was 5.6 years. Sixty-one patients $(52 \% .1)$ had stage IA, 20 patients (17\%) had stage IB, 31 patients (26.4\%) had stage IIA, 3 patients $(2.5 \%)$ had IIB stage, 1 patient $(0.85 \%)$ had IIIB stage and 1 patient $(0.85 \%)$ had IVA stage of the disease. Atypical forms of the disease were detected in $6(5.1 \%)$ patients. Three $(2.5 \%)$ of these cases were follicular MF, one patient for each types of hypopigmented, ichthyosiform and granulomatous MF (Figures 1-4). Demographic and clinical features of all patients are shown in Table 1, and atypical forms are shown in detail in Table 2.

All patients were treated with medium-potent topical corticosteroids. Additionally 99 (84.6\%) patients received phototherapy, 20 patients (17\%) acitretin, 6 patients (5.1\%) topical bexarotene, 4 patients $(3.4 \%)$ methotrexate and 1 patient $(0.85 \%)$ systemic interferon treatment. Of the patients who received phototherapy 30 had Psoralen Ultraviolet $A$ (PUVA), 46 had narrow band UVB (nb-UVB) and 12 had both PUVA and $n b-U V B$ during follow-up. Acitretin was added to 13 of the patients who received phototherapy, 9 patients had acitretin with PUVA, 7 patients had acitretin with nb-UVB, and 3 had both UVB and UVA treatment with acitretin during follow-up.

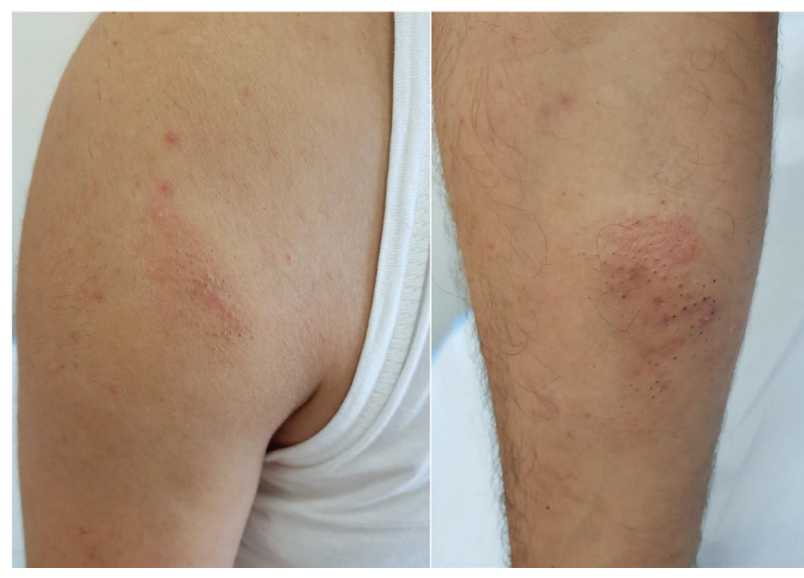

Figure 1. Erythematous, follicular and comedonal plaques on extremitites

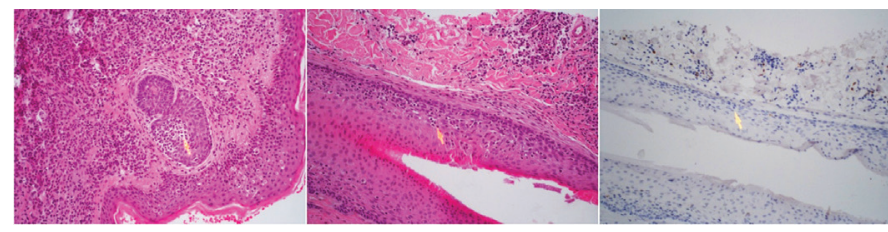

Figure 2. Intense lymphocytic infiltration under the epidermis. Lymphocytes tend to clump within the hair follicle epithelium (x200) Loss of CD7 expression of lymphocytes in the hair follicle epithelium (x200)

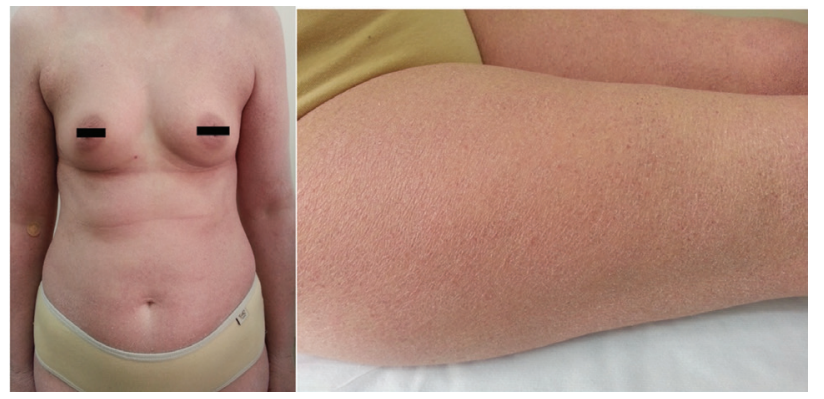

Figure 3. Diffuse xerosis, erythema and ichtiosiform scales on extremities and trunk

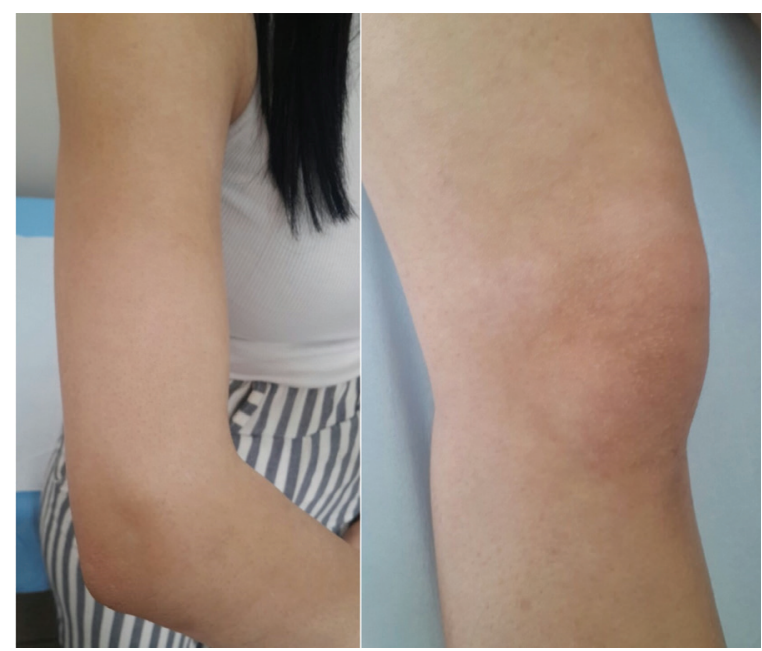

Figure 4. Hypopigmented patches on extremities 


\section{Discussion}

MF is the most common primary cutaneous T-cell lymphoma and its annual incidence is ranged from 0.13 to 0.9 cases per 100.000 people? MF usually presents in the fifth and sixth decades of life and the disease shows male predominance ${ }^{5-8}$. In classic MF, the patients usually present with slightly erythematous, scaly patches, plaques and tumors located on non-sun exposed areas and clinical features may resemble various inflammatory dermatoses such as atopic dermatitis and psoriasis $2,6,8,9$. In literature, there are studies describing the clinical and epidemiological features of MF patients in countries such as the United States, Kuwait and $\operatorname{Iran}^{7,8,10,11}$. Alsaleh et al. ${ }^{7}$ reported that the male/female ratio of the patients was 2 and the mean age of onset was 35.2 in Kuwait. In a study conducted by Desai et al. ${ }^{10}$ in Southeast America, 393 patients with MF and Sezary syndrome were evaluated. The male/female ratio was 1.1: 1 and the mean age at diagnosis was 53.7 years. In a study

Table 1. Demographic and clinical features of all MF patients

\begin{tabular}{|c|c|}
\hline \multicolumn{2}{|l|}{ Age } \\
\hline - Range & $20-89$ \\
\hline - Median & 55 \\
\hline - Mean ( $\pm S D)$ & $55.69 \pm 16.03$ \\
\hline \multicolumn{2}{|l|}{ Sex } \\
\hline - Female & $64(54 \%)$ \\
\hline - Male & $53(46 \%)$ \\
\hline \multicolumn{2}{|c|}{ Disease duration (month) } \\
\hline - Range & $2-480$ \\
\hline - Median & 36 \\
\hline - Mean & 68.7 \\
\hline \multicolumn{2}{|l|}{ MF types } \\
\hline - Classic & $111(94.9 \%)$ \\
\hline - Atypical & $6(5.1 \%)$ \\
\hline \multicolumn{2}{|l|}{ Stage } \\
\hline$-I A$ & $61(52.1 \%)$ \\
\hline$-I B$ & $20(17 \%)$ \\
\hline - IIA & $31(26.4 \%)$ \\
\hline$-\| \mathrm{B}$ & $3(2.5 \%)$ \\
\hline$-\mid I I B$ & $1(0.85 \%)$ \\
\hline - IVA & $1(0.85 \%)$ \\
\hline \multicolumn{2}{|c|}{ SD: Standard deviation, MF: Mycosis fungoides } \\
\hline
\end{tabular}

from Iran this ratio was 1: 1.2 and the age of onset was 41 years while in a study from Syria this ratio was 2: 1 and the mean age was found to be 33.5 years ${ }^{8,11}$. In our study, the ratio of male to female was 0.82 . The mean age at diagnosis of our patients was 55.6 years which is similar with Desai et al. ${ }^{10}$ however it was higher than other studies.

The staging system of the disease was revised by EORTC in 2007. MF is classified into early (stage IA, IB and IIA) and advanced (stage IIB, III and IV) stages according to progression and prognosis of the disease $\mathrm{e}^{9,12}$. In literature, majority of the patients were reported to have early stage disease and this rate ranged from $77.9 \%$ to $93 \% 7,8,10,11$. Similarly, in our study $95.5 \%$ of patients were in early stage (1A-1B-2A).

Early-stages of the MF are treated with skin-directed treatments such as topical agents (corticosteroid, nitrogen mustards, carmustine and bexarotene), electron beam therapy, phototherapy (oral psoralen plus UVA, nb-UVB), while in advanced -stage interferon-alfa, systemic retinoids, methotrexate, extracorporeal photopheresis, systemic chemotherapy are the treatment options ${ }^{9,12}$. PUVA and nb-UVB are the most commonly used phototherapies, and complete response rates with nb-UVB at early stage reach up to $54 \%$ to $90 \%$. PUVA should be preferred in thick plaque-type lesions, it can penetrate deeper than nb-UVB. PUVA and nb-UVB show similar results in terms of complete remission rates and mean relapse-free interval. Combination of systemic agents such as retinoids, bexarotene and alpha interferon with phototherapy is widely used to increase the effectiveness of PUVA, to provide long-term remission and to reduce total ultraviolet exposure $^{9,13}$. Stage of the disease, immunophenotypic findings, age and the presence of comorbidities should be considered when systemic treatment options are decided ${ }^{12}$. In our study all patients were treated with medium potent topical corticosteroids. Additionally 99 (84.6\%) patients received phototherapy, 20 patients (17\%) acitretin, 6 patients (5.1\%) topical bexarotene, 4 patients $(3.4 \%)$ methotrexate and 1 patient $(0.85 \%)$ systemic interferon.

Fatemi Naeini et al. ${ }^{8}$ reported that $79 \%$ of MF cases were classic MF in their study, while in our study $94.9 \%$ of patients were classic form of MF. Atypical forms of the disease were detected in $6(5.1 \%)$ cases. Three $(2.5 \%)$ of these cases were follicular MF, one patient for each types of hypopigmented, ichthyosiform and granulomatous MF. Follicular MF is a variant of cutaneous CD4+ T-cell lymphoma characterized with infiltration of hair follicles with atypical lymphocytes. The clinical presentation of follicular MF includes alopecia, follicular papules, acneiform lesions, cysts and leonine face. Head, neck, trunk and extremities are predilection sites ${ }^{14,15}$. In a study with 33 follicular MF patients, $93.9 \%$ of the patients presented predominantly with the involvement of extremities ${ }^{15}$. Similarly in our study extremities (66\%)

Table 2. Demographic and clinical features of mycosis fungoides variants and subtypes

\begin{tabular}{|l|l|l|l|l|l|l|}
\hline Patient & Age & Sex & Subtype & Disease duration & Localization \\
\hline 1 & 20 & F & Follicular & $3 \mathrm{~m}$ & Back, legs \\
\hline 2 & 32 & M & Follicular & $3 \mathrm{y}$ & Extremities & Re-PUVA \\
\hline 3 & 51 & M & Follicular & $6 \mathrm{y}$ Reck & Acitretin \\
\hline 4 & 40 & F & Hypopigmented & $1 \mathrm{y}$ & Trunk, extremities \\
\hline 5 & 40 & F & Ichthyosiform & $10 \mathrm{y}$ & Face, scalp, trunk, extremities & Acitretin \\
\hline 6 & 80 & M & Granulomatous & $6 \mathrm{~m}$ & Trunk, axilla, inguinal region & Re-PUVA \\
\hline F: Female, M: Male, m: Month, $\mathrm{y}:$ Year, Re-PUVA: Retinoid-psoralen Ultraviolet A & & \\
\hline
\end{tabular}


were the most commonly affected sites of the disease. Follicular MF is histopathologically characterized by infiltration of hair follicles and eccrine sweat glands with neoplastic T-cells and epidermotropism. Perifollicular lymphocytic infiltration is the most common finding in the literature and similar results were also identified in our 3 patients ${ }^{16,17}$. In addition, atypia, nuclear enlargement and contour irregularity were detected in our 3 patients. While Marschalkó et al. ${ }^{16}$ found keratin plug formation in 4 (17\%) of 17 follicular MF patients, in our cases only 1 patient (33\%) had keratin plug formation. Follicular MF patients are considered to be at advanced stage at the time of diagnosis and systemic treatments should be considered. Infiltration of hair follicles by neoplastic T-cells limits the effectiveness of superficial treatments such as topical steroids or phototherapy. Therefore, other treatment modalities such as oral retinoids, bexarotene, local radiotherapy, isotretinoin, methotrexate, interferon, total body electron beam therapy should be considered ${ }^{15,17}$. Our 3 patients with follicular MF were treated with combination of PUVA and acitretin.

Hypopigmented MF is another clinical variant with asymptomatic irregular, vitiligo-like patches located on proximal extremities and trunk, generally observed in dark-skinned children and young adults. In differential diagnosis of this condition various dermatoses such as atopic dermatitis, pityriasis alba, postinflammatory hypopigmentation, sarcoidosis, lichen sclerosis should be considered. The prognosis is better than other MF subtypes, and in early stage of MF a successful response to treatment is usually achieved. Photochemotherapy is the first step of treatment and nb-UVB is recommended for children. Topical steroid and acitretin were used in the treatment of our patient ${ }^{4}$. Ichthyosiform MF is a subtype which is considered in the differential diagnosis of acquired ichthyosis with its clinical and histopathological findings are similar to other MF variants. Ichthyosiform eruption may be sole clinical finding or it may be seen in combination with classical or follicular MF lesions. The most common symptom is pruritus and ichthyosiform lesions can be observed throughout the body ${ }^{18,19}$. Jang et $a .^{18}$ evaluated 10 patients with ichthyosiform MF and reported that 7 of the patients were male and 3 were female. Seven patients had ichthyosiform lesions all over their body, one of them had also lesions on the face and scalp, while 3 remaining patients had lesions only on the trunk and extremities. In 4 of the patients ichthyosiform lesions were the only symptom of the disease. Our ichthyosiform MF patient was female, the lesions were present on the whole body, face and scalp. This patient manifested only ichthyosiform lesions without classical MF lesions

Granulomatous MF is a rare variant of cutaneous T-cell lymphomas. Clinical presentation is in the form of non-specific erythematous papules, plaques similar to other MF subtypes and the development of poikiloderma also has been described. Since the clinical presentation is similar to classical MF lesions, the diagnosis of granulomatous MF depends on the histopathological examination of the lesions and usually a malignant lymphoid infiltrate concomitant with granulomatous inflammatory reaction are observed ${ }^{20}$. Li et al. ${ }^{1}$ evaluated 27 patients with granulomatous MF and reported that they constitute $6.3 \%$ of all MF patients. In our study only 1 patient $(0.8 \%)$ had granulomatous MF. Skin-targeted therapies may be insufficient to treat granulomatous MF and patients usually require systemic treatment even in the early stages ${ }^{1}$. Accordingly our patient was treated with combination of acitretin and PUVA.
In addition, there are many variants and subtypes of MF including hyperpigmented, hyperkeratotic/verrucous, bullous, pustular, porokeratotic, poikilodermic, syringotrophic, purpuric, erythrodermic, palmoplantar, unilateral, pityriasis lichenoides like $\mathrm{e}^{1,3-5}$. In our study 3 (2.5\%) of these cases were follicular MF, one patient for each types of hypopigmented, ichthyosiform and granulomatous MF. There were no patients with other variants and subtypes.

\section{Study Limitation}

Retrospective design is the limitation of our study.

\section{Conclusion}

MF variants, subtypes, atypical forms and early lesions of MF may cause delay in the diagnosis and treatment by mimicking other dermatoses. These variants, subtypes may differ from classical MF in terms of clinical findings, prognosis and response to treatment. Therefore suspicion of MF is warranted for early diagnosis and treatment of MF variants, subtypes, atypical forms of MF.

\section{Ethics}

Ethics Committee Approval: The study protocol was approved by Eskişehir Osmangazi University Ethics Committee (approval number: 11, date: 03.07.2018).

Informed Consent: Retrospective study.

Peer-review: Externally peer-reviewed.

\section{Authorship Contributions}

Surgical and Medical Practices: H.K.E., E.A., D.A., Concept: H.K.E., E.A., E.Ac., Design: H.K.E., E.A., E.Ac., Data Collection or Processing: H.K.E., E.A., E.Ac., D.A., Analysis or Interpretation: H.K.E., E.A., E.Ac., D.A., Z.N.S., Literature Search: H.K.E., E.A., Writing: H.K.E., E.A.

Conflict of Interest: No conflict of interest was declared by the authors.

Financial Disclosure: The authors declared that this study received no financial support.

\section{References}

1. Li JY, Pulitzer MP, Myskowski PL, et al: A case-control study of clinicopathologic features, prognosis, and therapeutic responses in patients with granulomatous mycosis fungoides. J Am Acad Dermatol 2013;69:36674

2. Engin B, Uzun A, Kutlubay Z, Tüzün Y. Mikozis fungoides güncel. Dermatoz 2016:1.

3. Jang MS, Kang DY, Park JB, et al: Pityriasis lichenoides-like mycosis fungoides: clinical and histologic features and response to phototherapy. Ann Dermatol 2016;28:540-7.

4. Furlan FC, Sanches JA: Hypopigmented mycosis fungoides: a review of its clinical features and pathophysiology. An Bras Dermatol 2013;88:954-60.

5. Kazakov DV, Burg G, Kempf W: Clinicopathological spectrum of mycosis fungoides. J Eur Acad Dermatol Venereol 2004;18:397-415.

6. Virmani P, Levin L, Myskowski PL, et al: Clinical outcome and prognosis of young patients with mycosis fungoides. Pediatr Dermatol 2017;34:547-53.

7. Alsaleh QA, Nanda A, Al-Ajmi $\mathrm{H}$, et al: Clinicoepidemiological features of mycosis fungoides in Kuwait, 1991-2006. Int J Dermatol 2010;49:1393-8.

8. Fatemi Naeini F, Abtahi-Naeini B, Sadeghiyan H, Nilforoushzadeh MA, Najafian J, Pourazizi M: Mycosis fungoides in Iranian population: an epidemiological and clinicopathological study. J Skin Cancer 2015;2015:306543.

9. Jang MS, Baek JW, Park JB, et al: Narrowband ultraviolet B phototherapy of early stage mycosis fungoides in korean patients. Ann Dermatol 2011:23:474-80 
10. Desai M, Liu S, Parker S: Clinical characteristics, prognostic factors, and survival of 393 patients with mycosis fungoidesand Sézary syndrome in the southeastern United States: a single-institution cohort. J Am Acad Dermatol 2015;72:276-85.

11. AlGhamdi KM, Arafah MM, Al-Mubarak LA, Khachemoune A, Al-Saif FM: Profile of mycosis fungoides in 43 Saudi patients. Ann Saudi Med 2012;32:283-7.

12. Photiou L, van der Weyden C, McCormack C, Miles Prince H: Systemic treatment options for advanced-stage mycosis fungoides and Sézary Syndrome. Curr Oncol Rep 2018;20:32.

13. Hodak E, Pavlovsky L: Phototherapy of mycosis fungoides. Dermatol Clin 2015;33:697-702.

14. Mantaka P, Helsing P, Gjersvik P, Bassarova A, Clausen OP, Delabie J: Clinical and histopathological features of folliculotropic mycosis fungoides: a Norwegian patient series. Acta Derm Venereol 2013;93:325-9.

15. Deonizio JM, Ascef RD, Sanches JA: Folliculotropic mycosis fungoides: clinical and epidemiological evaluation in a single center in Brazil. Int J Dermato 2016;55:e256-61
16. Marschalkó M, Erôs $\mathrm{N}$, Kontár $\mathrm{O}$, et al: Folliculotropic mycosis fungoides: clinicopathological analysis of 17 patients. J Eur Acad Dermatol Venereol 2015;29:964-72.

17. Wieser I, Wang C, Alberti-Violetti S, et al: Clinical characteristics, risk factors and long term outcome of 114 patients with folliculotropic mycosis fungoides. Arch Dermatol Res 2017;309:453-9.

18. Jang MS, Kang DY, Park JB, et al: Clinicopathological manifestations of ichthyosiform mycosis fungoides. Acta Derm Venereol 2016;96:100-1.

19. Hodak E, Amitay I, Feinmesser M, Aviram A, David M: Ichthyosiform mycosis fungoides: an atypical variant of cutaneous T-cell lymphoma. J Am Acad Dermatol 2004:50:368-74.

20. Fischer M, Wohlrab J, Audring TH, Sterry W, Marsch WC: Granulomatous mycosis fungoides. Report of two cases and review of the literature. J Eur Acad Dermatol Venereol 2000;14:196-20. 